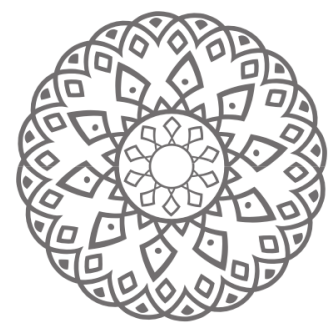

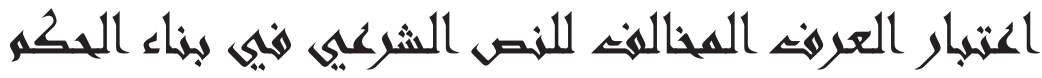

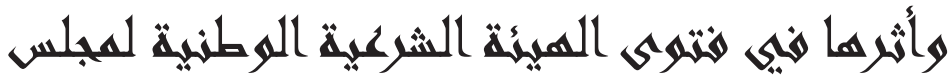

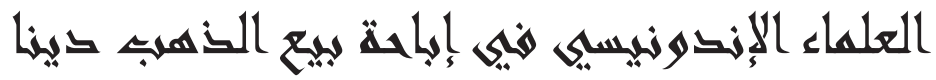

\section{Bukhori Muslim}

\begin{abstract}
Abstrak: Penelitian ini menjelaskan pentingnya menjaga 'Urf dalam fatwa perspektif para Ushuli, terkait 'urf yang berseberangan dengan nash syar'i serta untuk menguraiakn bagimana konsep mempertimbankan 'urf tersebut mempengaruhi fatwa DSN MUI dalam menerbitkan fatwa tentang jual beli emas secara tidak tunai. Penelitian ini menujukkan bahwa 'urf memiliki ranah yang luas dalam fatwa dan sangat penting untuk diperhatikan dalam istinbath hukum. Bahkan sekalipun 'urf tersebut bertentangan dengan nash, yaitu ketika nash tersebut memiliki 'illat hukum berupa 'urf, atau karena 'urf yang sedang berlaku menghilangkan 'illat hukum dari nash, atau ketika suatu 'urf terbentuk lantaran suatu keadaan mendesak (dharuri). Fatwa DSN MUI terkait kebolehan jual beli emas secara tidak tunai dipengaruhi oleh konsep'urf tersebut, dimana DS MUI memperhatkan daua bentuk 'urf: pertama: kebiasaan masyarakat dalam membeli emas dilakkan secara tidak tunai. Kedua: kebiasaan masyarakat yang tidak lagi menganggap emas sebagai alat tukar (uang), akan tetapi sebagai komuditas. Kebiasaan ini menurut DSN MUI menghilangkan ;Illat hukum dari nash yang melarang jual beli emas secara tidak tunai, lantaran emas adalah thaman (uang), sehingga tidak ada masalah dengan 'urf yang pertama. Metode penelitian ini adalah menggunakan metode deskriptif analisis perbandingan. Sumber primernya adalah fatwa DSN MUI nomor 77/DSN-MUI/2010.
\end{abstract}

Kata kunci: urf, jual beli emas, fatwa 


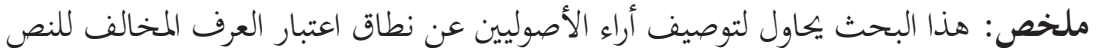

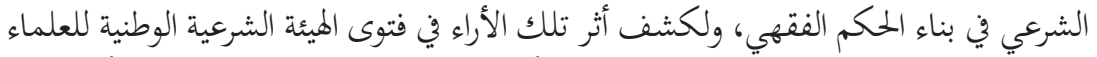

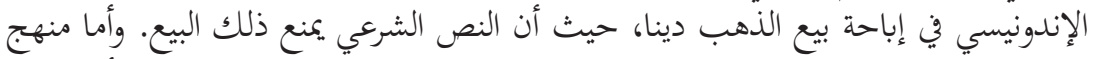

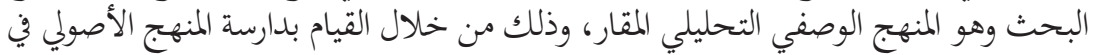

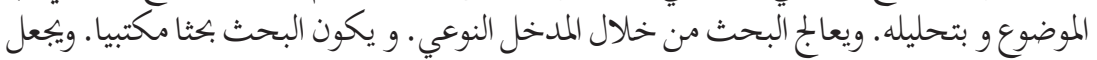

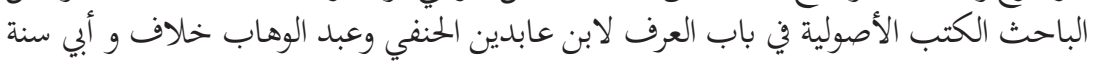

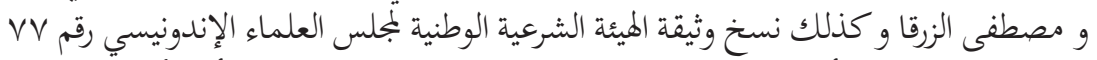

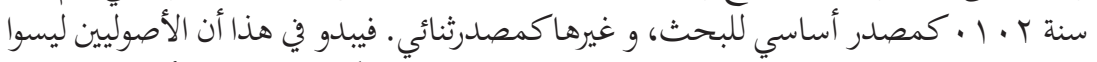

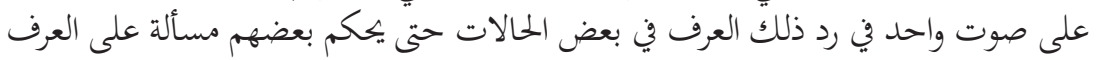

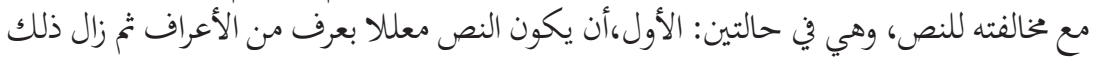

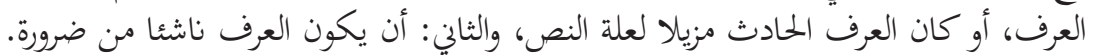

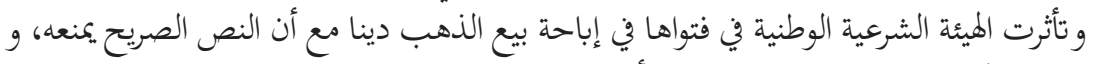

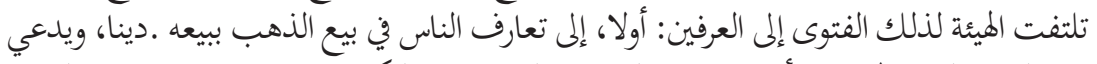

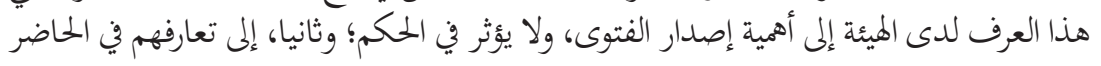

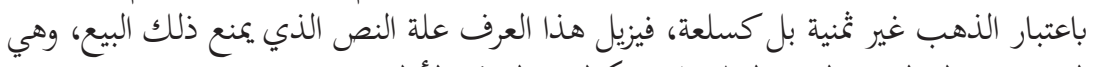
الثمنية، فيزول المنع بزواله، وبالتالي فلا إشكال فيلعة، فيريل هذا العرف الأول.

الكلمات المفتاحية: المظاهرات، الرقابة الشعبية، الفقه الإسلامي، القانون الوضعي 
المقدمة

يكون حكم من الأحكام الفقهية مبنيا على دليل من أدلة الأحكام'،

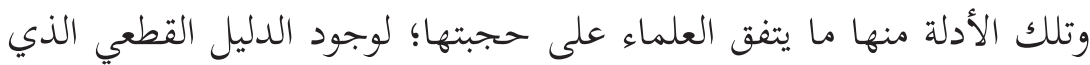

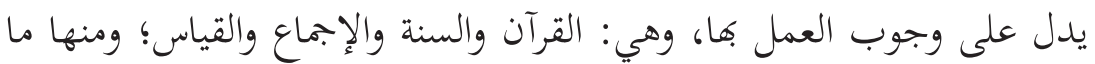

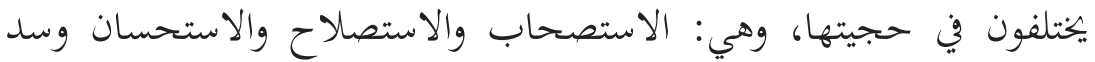

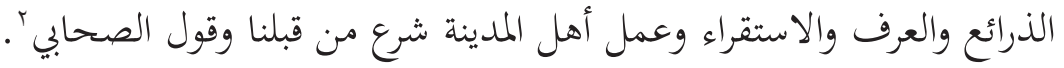
والعرف أو العادة، لكونه من جملة الأدلة المختلف فيها، فمن الضروري أن

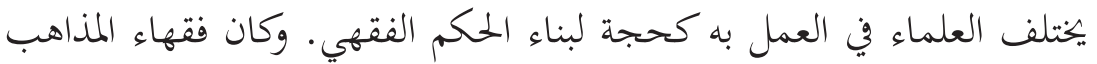

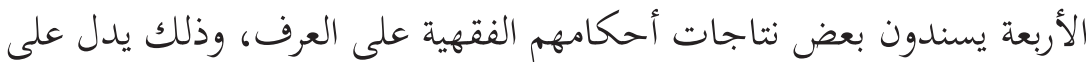
أفم اتفقوا على أن العرف أو العادة يكون من الحجة، وإنما اختلفوا في نطاق

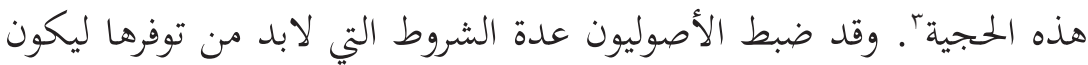

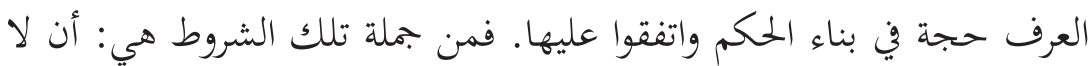

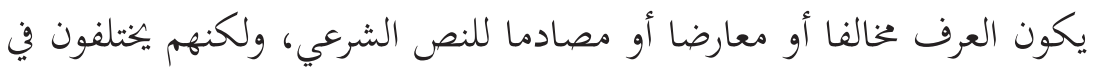
تحديد العرف حتى يعتبر مخالفا للنص الشرعي؛ وكانت الهيئة الشرعية الوطنية العلماء الإندونيسي في فتواها رقم لو سنة

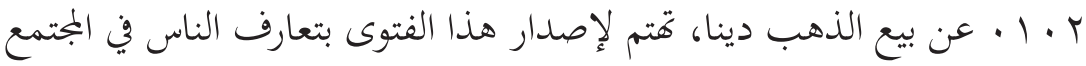

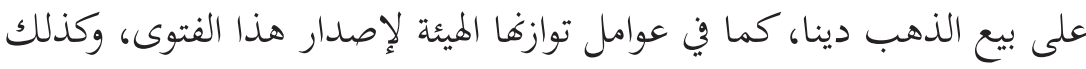
مما تأتي بها الهيئة كحجة للفتوى هي قاعدة العرف والعادة، وحاصله أت تحكي

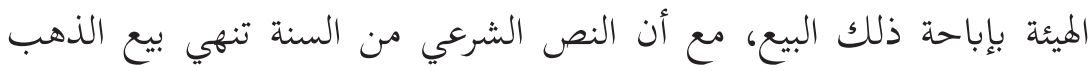
ويسمي الأصوليون أدلة الأحكام أيضا بـ مصادر الأحكام، انظر : عبد الوهاب خلاف، مصاف، مصادر

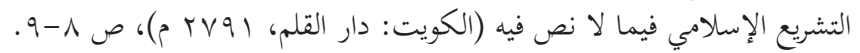

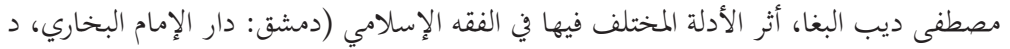

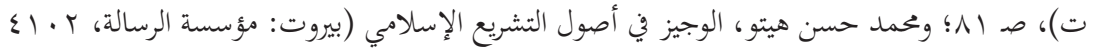
. VTE r بعقوب بن عبد عبدالوهاب الباحسين، قاعدة العادة محكمة دراسة نظرية تأصيلية تطبيقية (رياض:

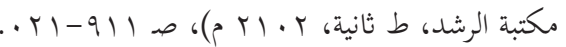

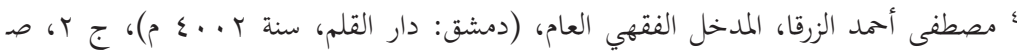


بالذهب دينا، وهذا النص قد أوردته الهيئة أيضا في مستند الفتوى كدليل يتعلق

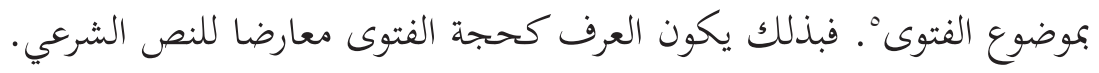

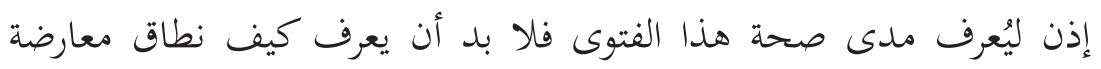

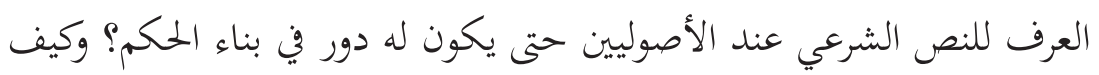
تستخدم الهيئة قاعدة العرف في ذلك الفئ الفتوى؟

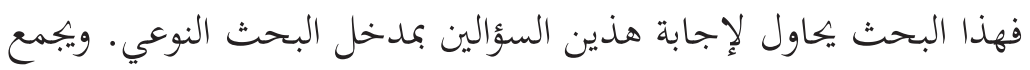

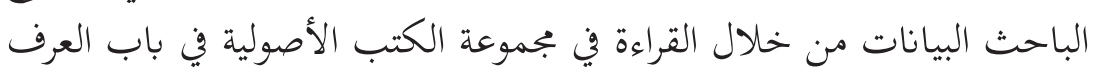

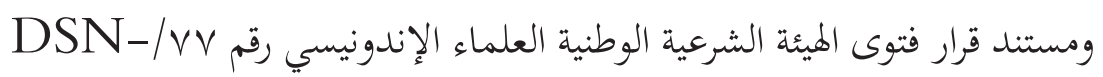

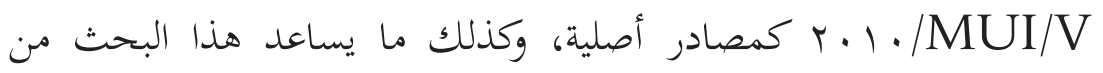
البجلات والبحوث العلمية كمصادر ثنائية.

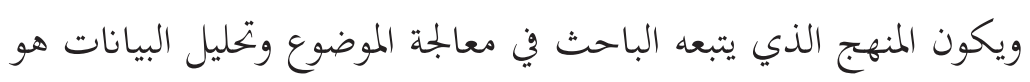

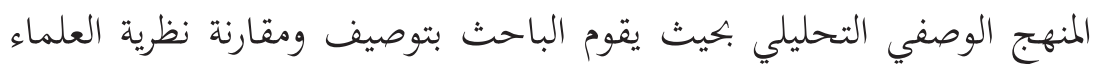

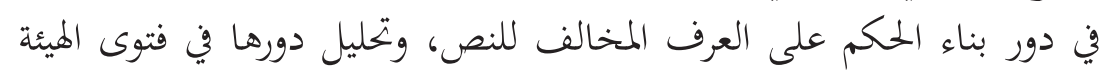

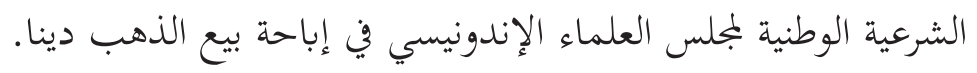

\section{نظرية العرف}

كلمة العرف لها عدة معان في أصل اللغة العربية، منها ما قال ابن منظور:

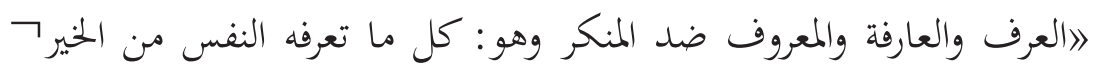

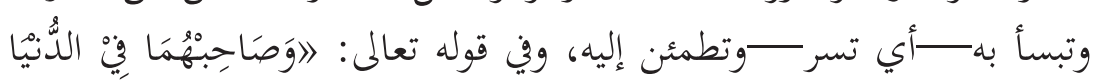

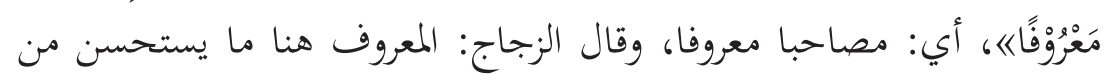

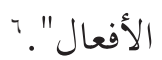

ولعرف تعاريف مخلتفة في اصطلاح الأصوليين مع متقاربتها في المعنى، منها

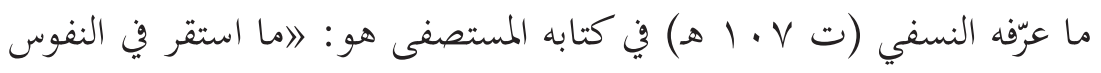

م الهيئة الشرعية الوطنية - بجلس العلماء الإندونيسي، فتوى رقم

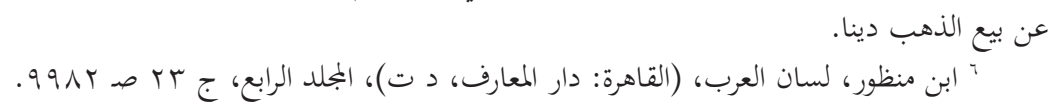




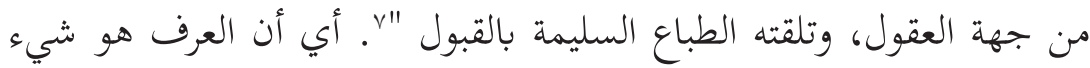

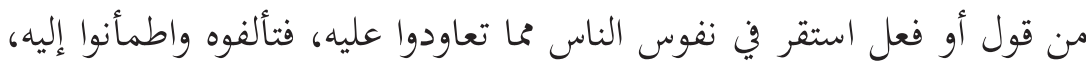

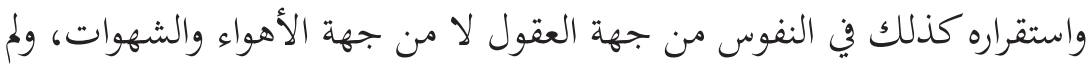

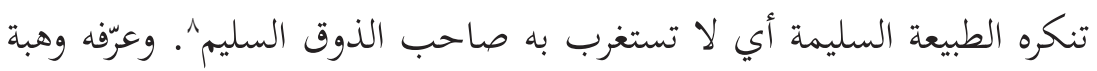

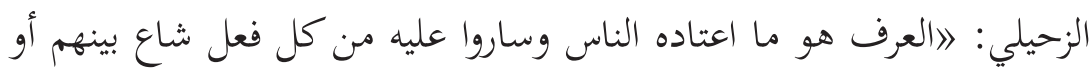

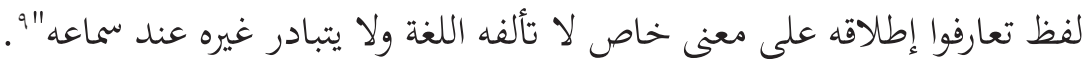

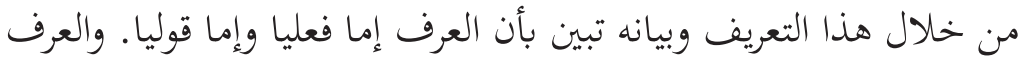

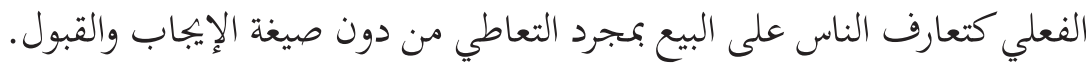

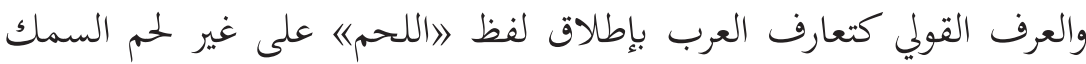

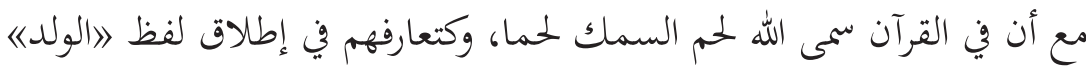

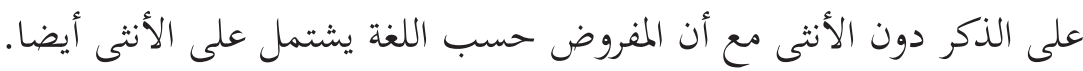

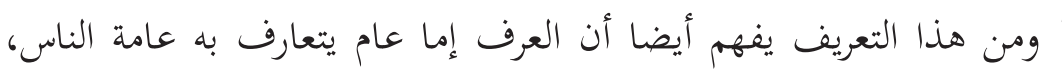

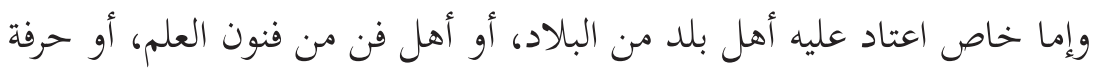

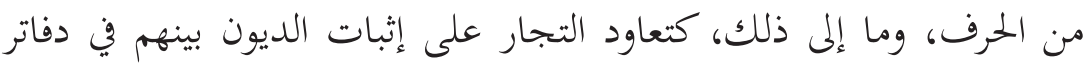

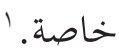
وكثير من العلماء استعملوا كلمة العرف والعادة على أفما لفظان مترادفان، إنهان

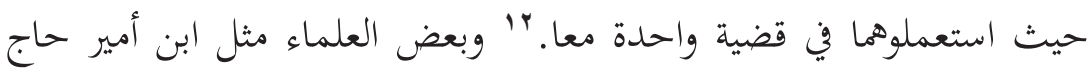

"عبد الله بن أحمد النسفي (ت V.1 إه)، "المستصفى"، في وهبة الزحيلي، أصول الفقه

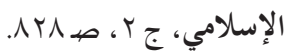

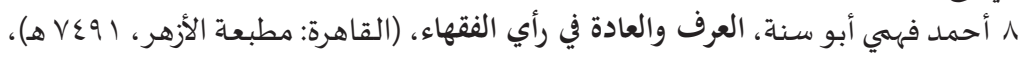

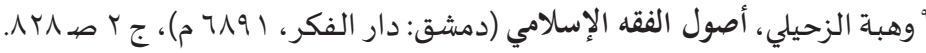

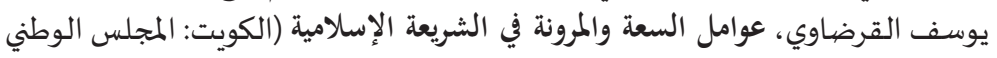

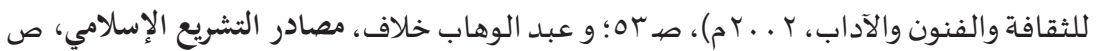

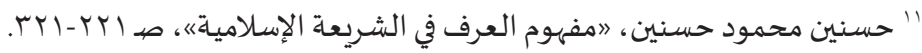

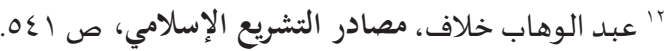


الحنفي"r يفرق بينهما حيث قال إن العادة يستعمل على ما صدر من الفرد

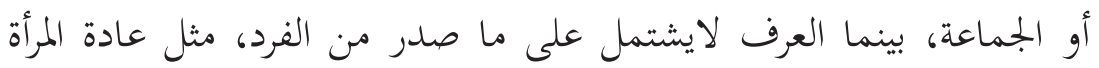

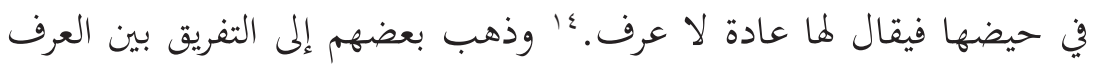

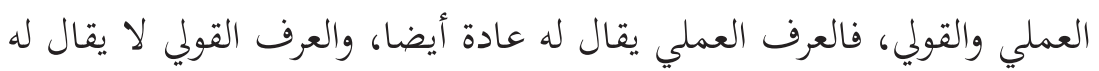
عادة 10.

\section{حجية العرف}

من كلام الأصوليين يبدو أن العرف لا يكون دليلا مستقلا الذي يشرع

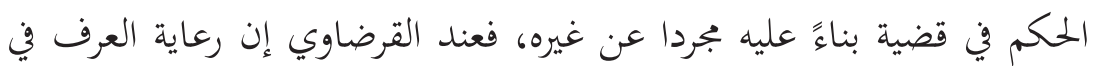

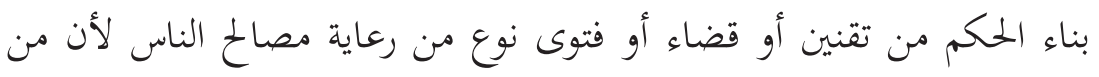

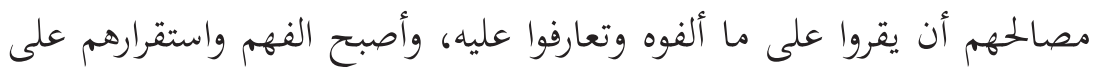
عاداهم من حوائجهم. 17

والعرف محا يتوصل به إلى فهم المراد من عبارات النصوص، ومن ألفاظ المتعاملين، ويتوصل به إلى تخصيص العام من الألفاظ وإلى تقييد المطلق منها. وكذلك يستند إلى العرف في تصديق قول أحد المتخاصمين إن لم توجد لأحده المها

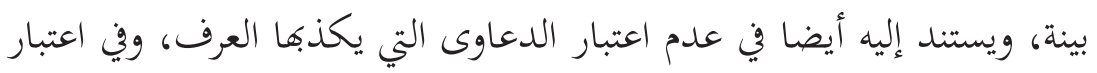

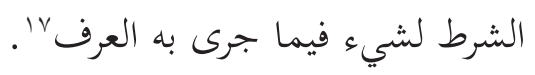

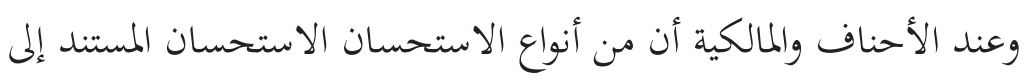

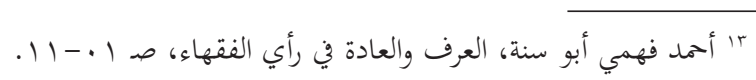

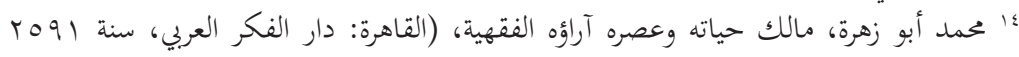
$. V \leq \varepsilon-6$ '. سعد الدين التفتازاني، شرح الثلويح على التوضيح، (مصر: مكتبة صبيح، د ت)، جا ص $.0 \mathrm{VI}$

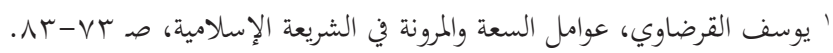

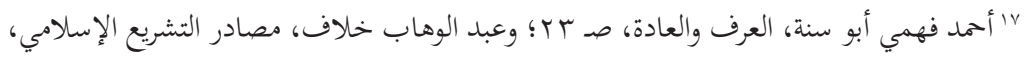


العرف، وكذلكأن العمل بالعرف أيضا قد يكون من مراعاة المصلحة المرسلة^^ .

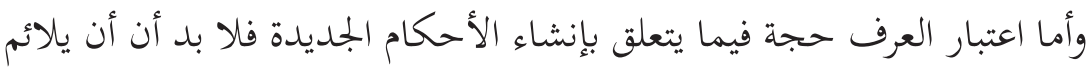

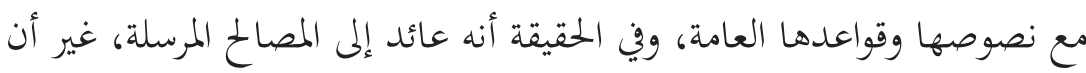

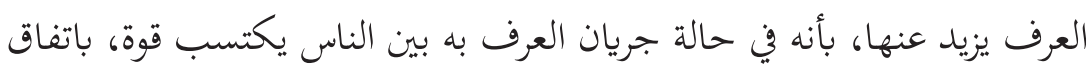
المسلمين أو أغلبهم على العمل بهله. 19

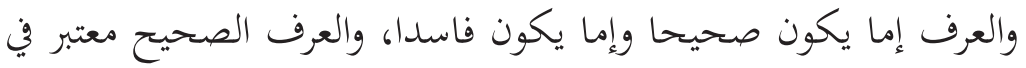

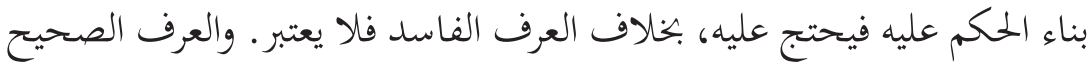

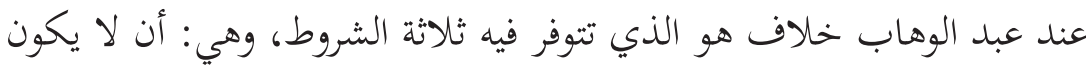

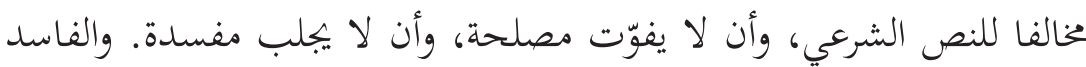

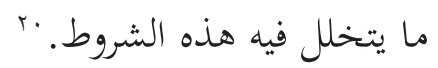

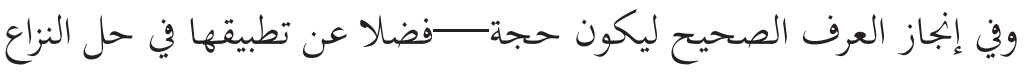

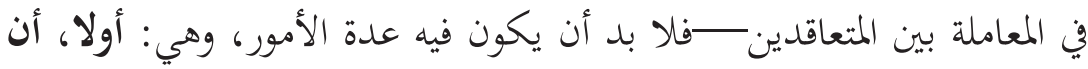

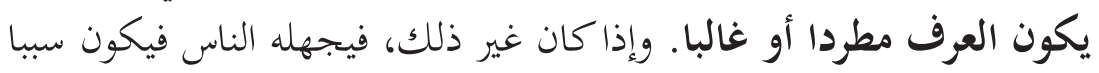

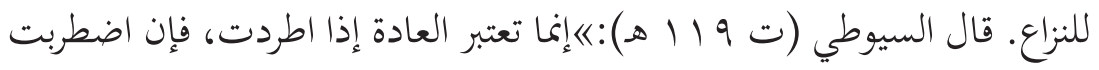

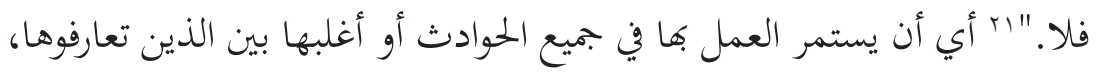

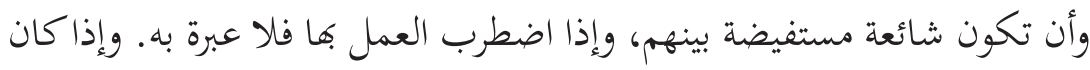

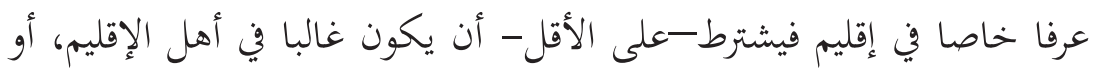

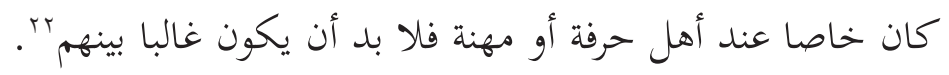

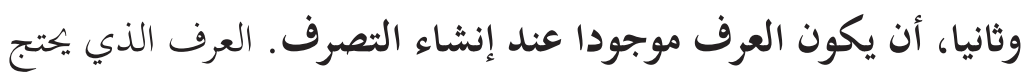

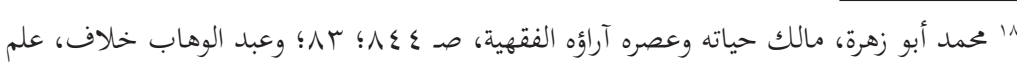

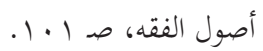

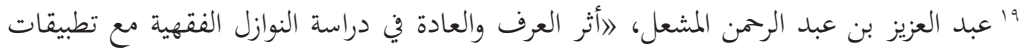

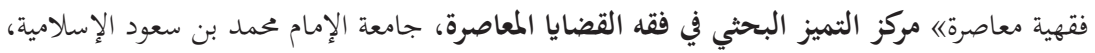

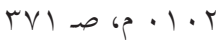

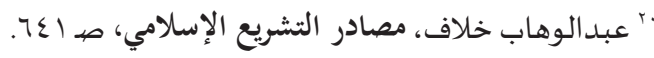

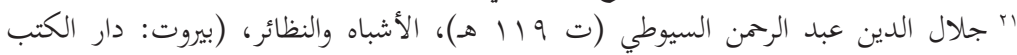

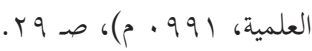

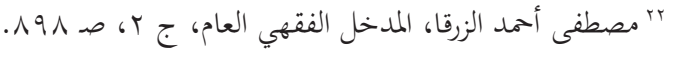


به في تصرف من التصرفات لا بد أن قد كان قبل تلك التصرف ويستمر في

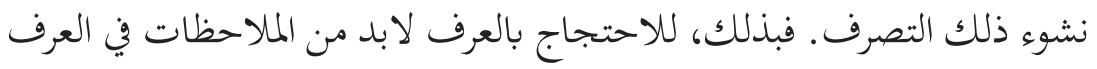

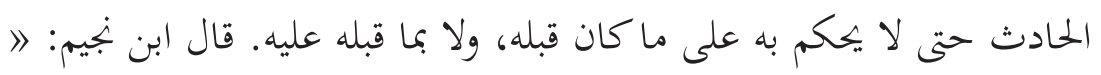

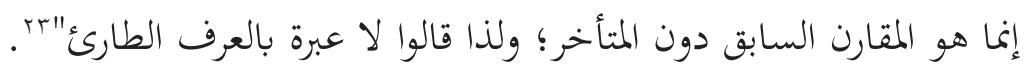
وثالثا، أن لا يعارضه تصريح بخلافه. وهذا الشرط يعني به قاعدة مشهورة

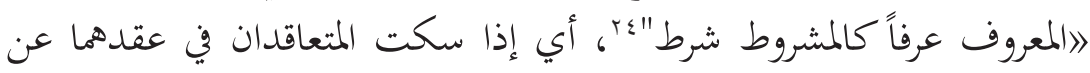

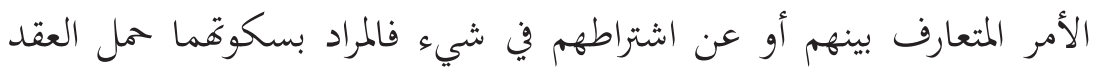

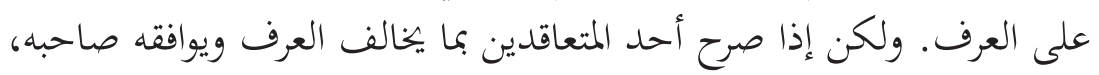

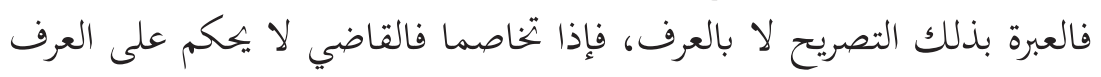

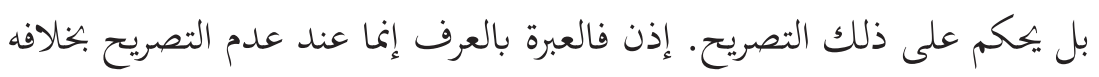

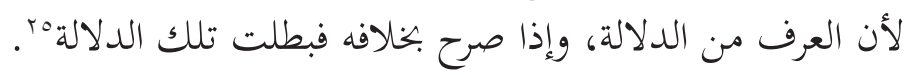

\section{دور العرف المخالف للنص الشرعي في بناء الحكم}

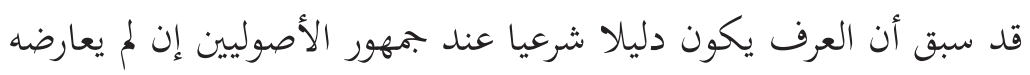
نص شرعي من الكتاب والسنة، حيث إذا اعتبر ذلك العرف يترتب به به تعطيل

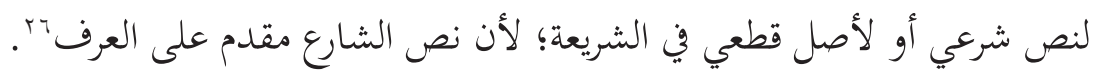

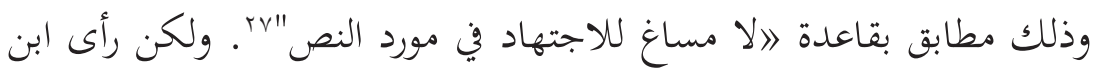

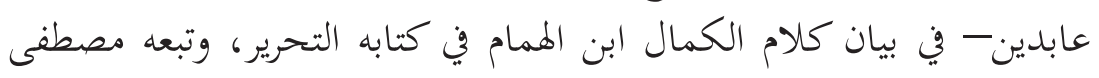

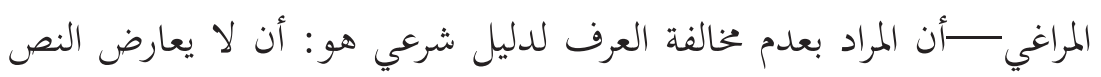

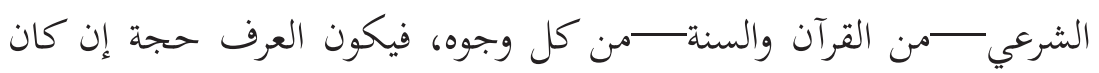

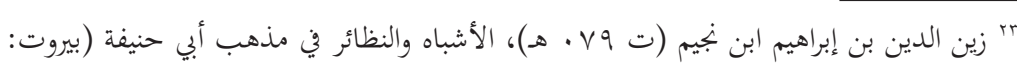

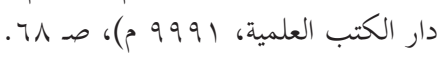
؟ ع بمد مصطفى الزحيلي، القواعد الفقهية وتطبيقها في المذاهب الأربعة (دمشق: دار الفكر،

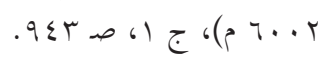

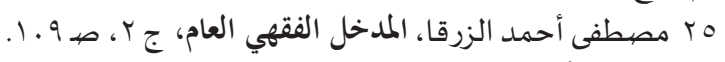

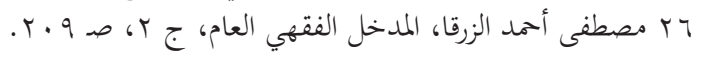

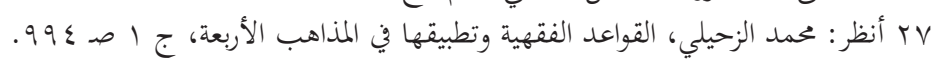


الدليل عاما والعرف يخالفه في بعض أفراده أو يكون الدليل قياسا^؟ . وانتقد أبو سنة على ابن عابدين في فهم المراد من كلام الكمال بن الهمام

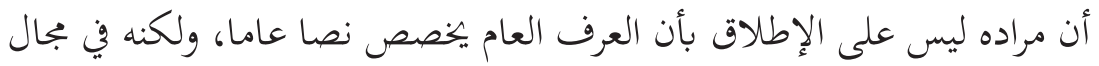

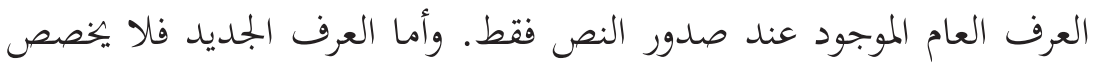

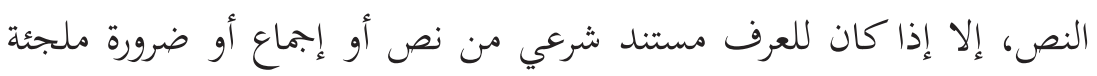

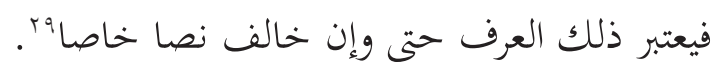
وانتقد الزرقا على أبي سنة في قوله ردا على ابن عابدين، فقال الزرقا إن أبي

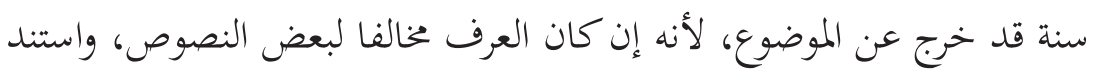
العرف إلى نص أخر أو إجماع أو ضرورى معتبرة، فلا تلكون المسألة في مجال

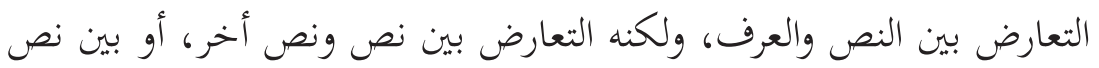

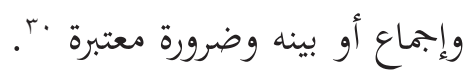
ورأى الزرقا أن قضية تعارض العرف للنص أن العرف الطارئ سواء كان

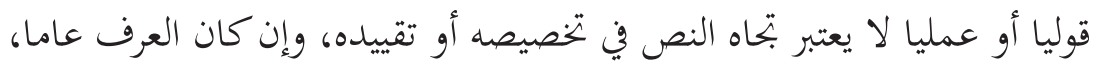

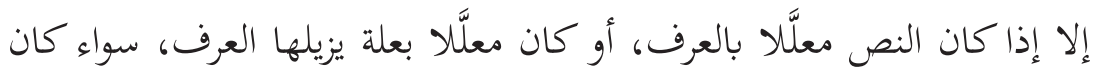

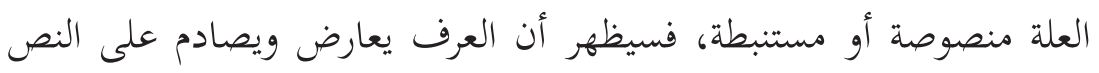
الشرعي 'بـ وهذا النظر ليست سليمة من مشكلة. ومن المشاكل التي تأتي

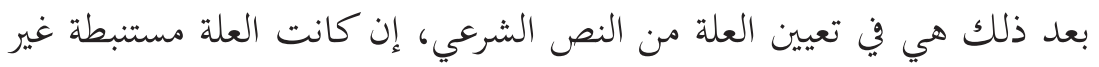

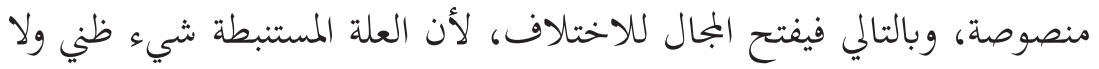

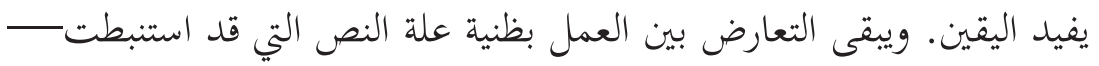

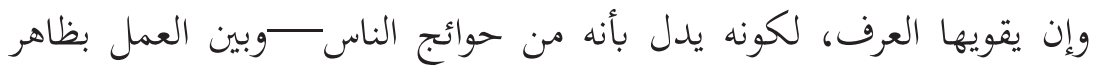
النص.

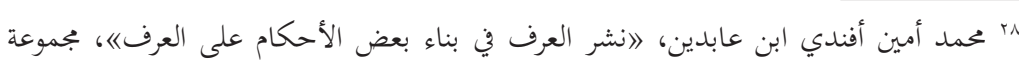

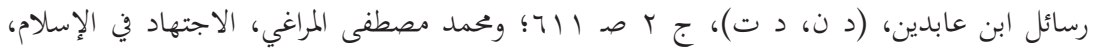

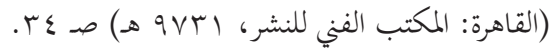

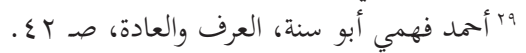

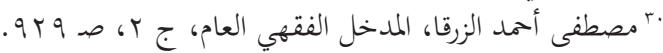

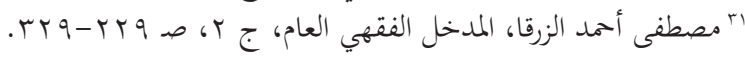


وهناك بعض العبارات من العلماء المعاصرين أن العرف الفاسد الذي

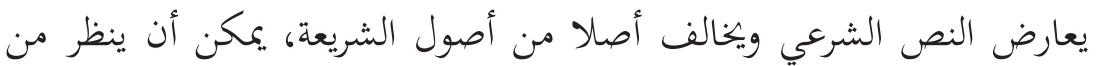

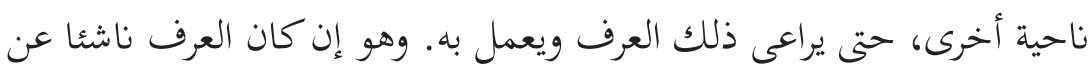

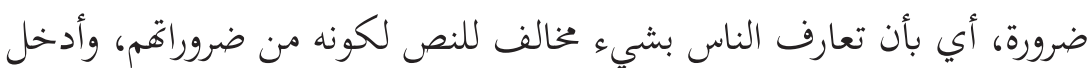
هذا العرف في باب الرخصة. وهذا ما وضحه محمد الخضر حسين -شيخ الأزهر

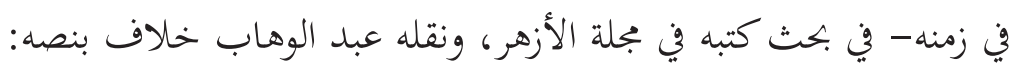
الويراعى العرف في القضاء والفتوى، وليس للفقيه أن يفتي أو يقضي بما

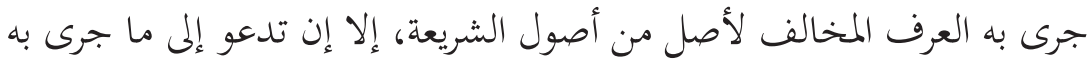

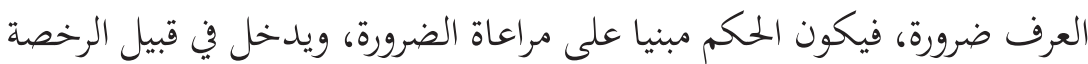

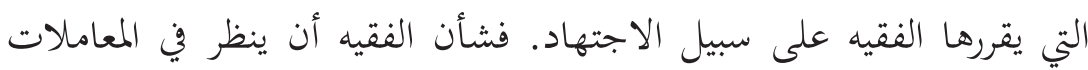

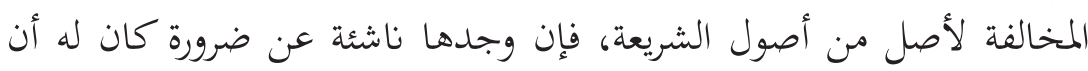

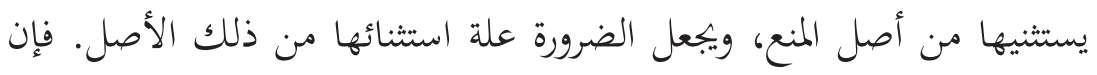

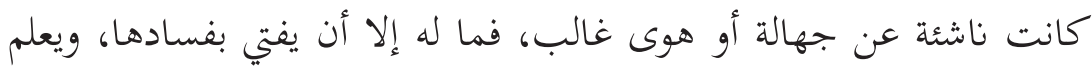
الناس وجه المعاملة الصحيحة) .

ومن مستندات هذا الرأي، كما بينه عبد الوهاب خلاف، أن الرسول

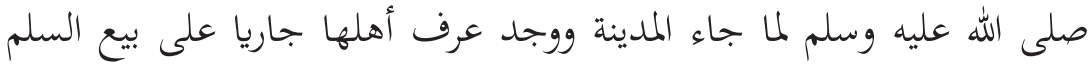

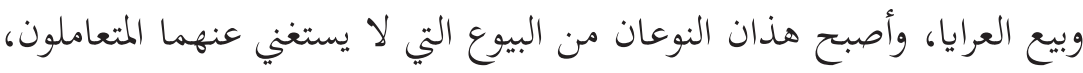

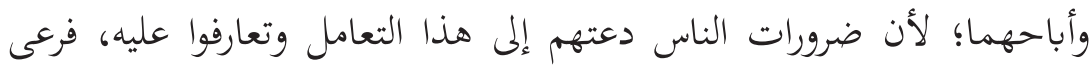
رسول الله ضرورتم وعرفهم، فرخص في السلم والعرايا، مع أن كلا منها مخالفا

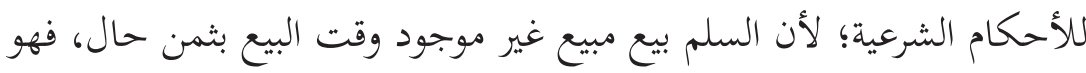

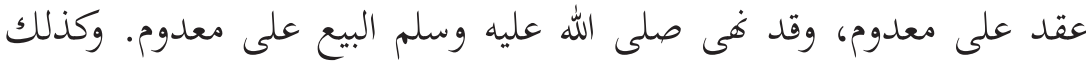

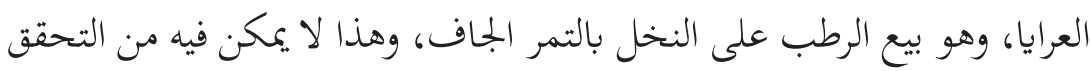

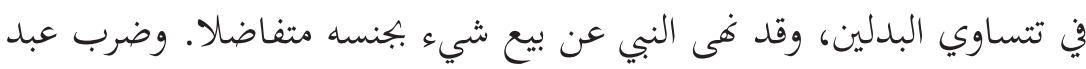

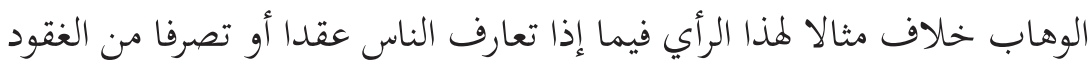

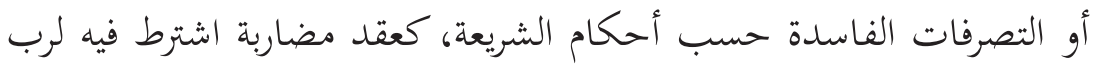




$$
\text { المال من الربح قدر معين لا نسبي، أو عقد من التأميناتج". }
$$

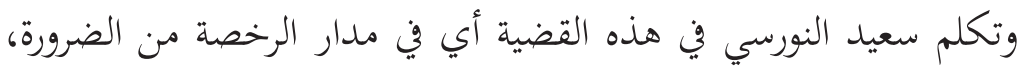

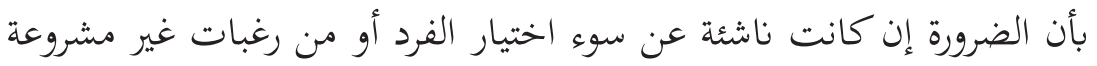

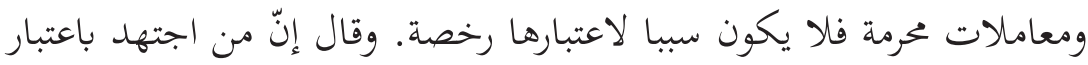

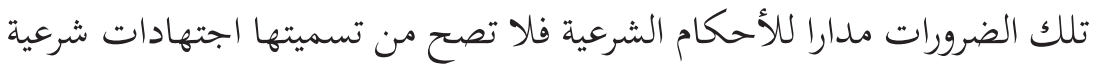

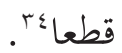

ورأى الباحث أن نطاق رأي محمد الخضر حسين ليس على إطلاقه، بل

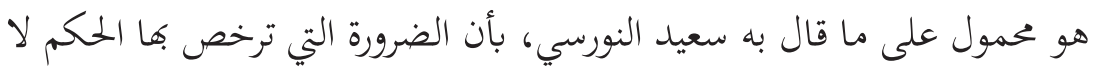

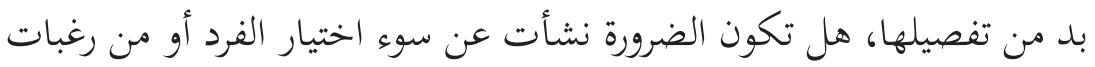

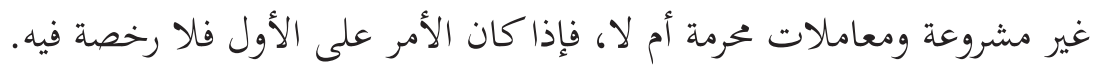

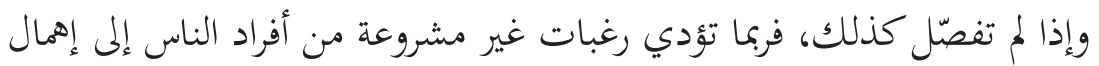

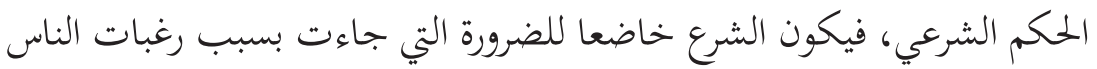
ولا يخضع الناس لحكمه.

\section{الهيئة الشرعية الوطنية لجلس العلماء الإندونيسي

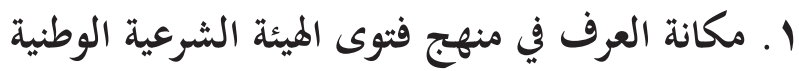

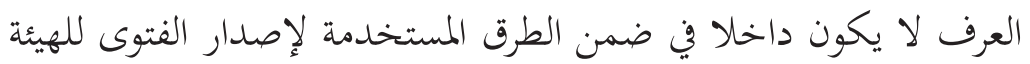

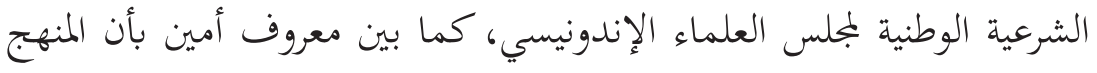

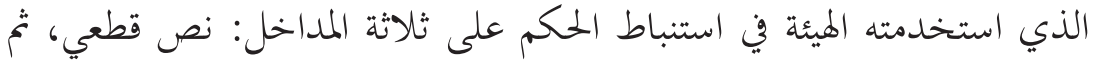

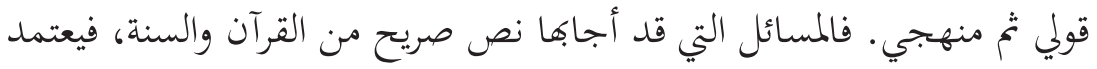

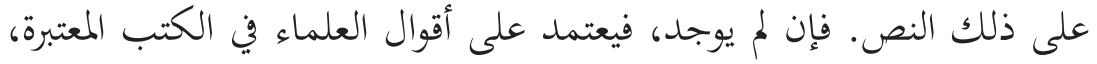

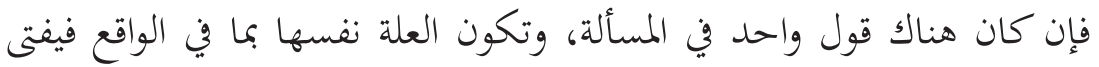

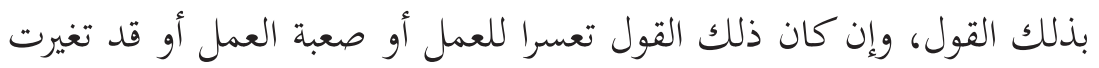

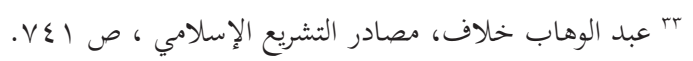

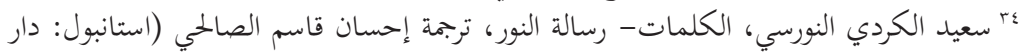


العلة فتعمل الهيئة بإعادة النظر مب.

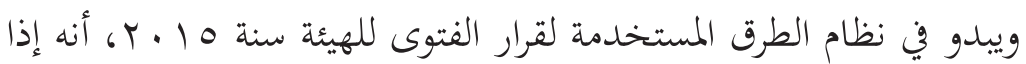

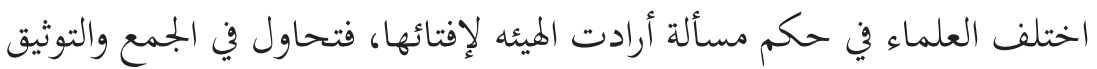

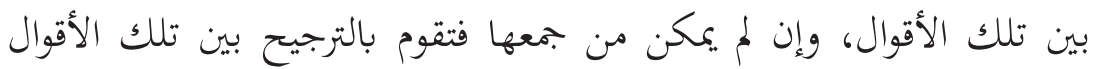

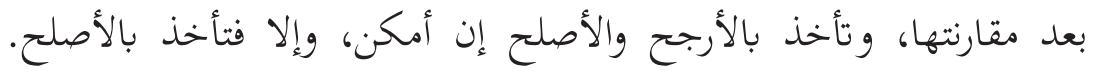

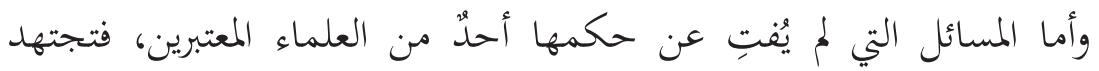

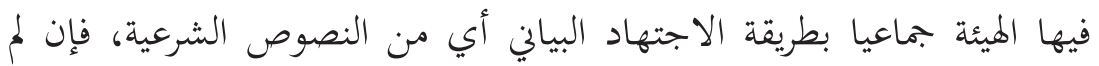
يمكن ذلك، فبطريقة الاجتهاد التعليلي التي تشتمل على القياسي والاستحساني

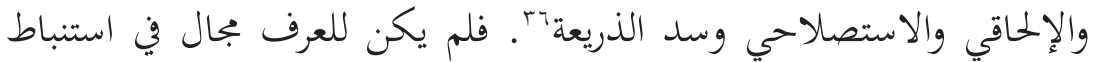
الأحكام حسب ذلك القرار، ولكنه يمكن أن يتضمن في الاجتهاد الاستحساني

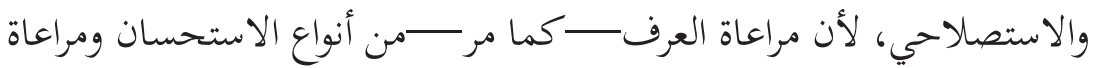

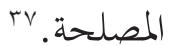

\section{Y.فتوى إباحة بيع الذهب دينا}

من خلال فتوى الهيئة الشرعية الوطنية لملس العلماء الإندونيسي بيعَ وشراءً

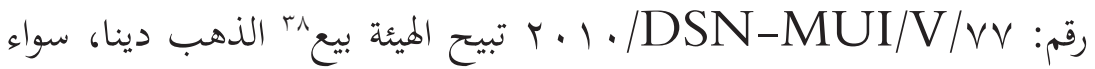

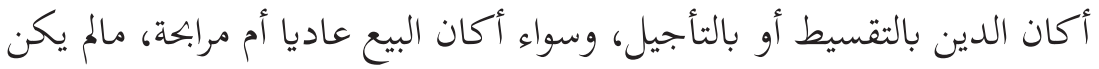

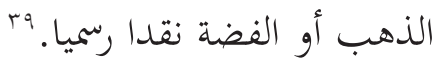

مrمعروف أمين، مخارج الفقهية (مالانج: جامعة مولانا مالك إبرهيم الإسلامية الحكومية مالانج)

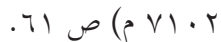
"بr بملس العلماء الإندونيسي، لادليل استنباط الحكم لمجلس العلماء اللإندونيسيه، نظام الأنظمة

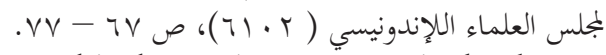
PO--.0/. • • . . / / http://test.islamwasathiyah.com/wp-content/uploads

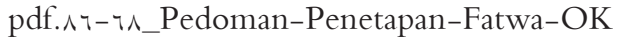

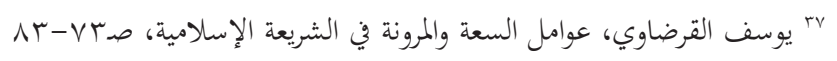

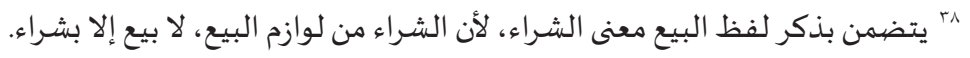

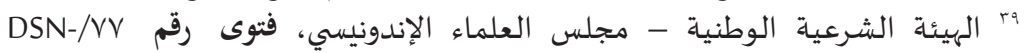

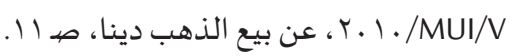


ومن العوامل التي توازنه الهيئة لأهمية إصدار الفتوى أن الناس في المجتمع

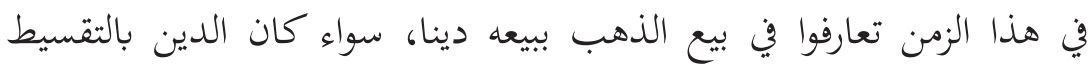

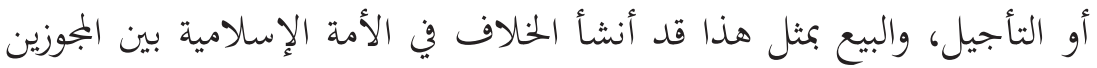

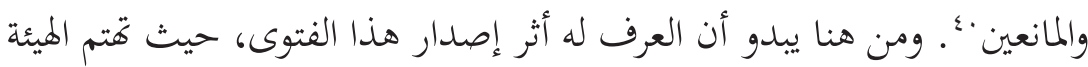

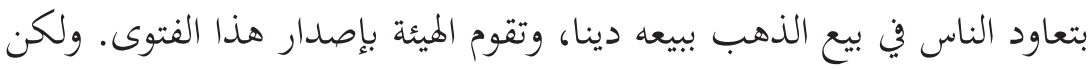

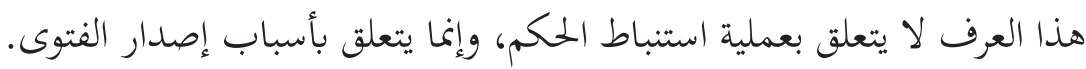

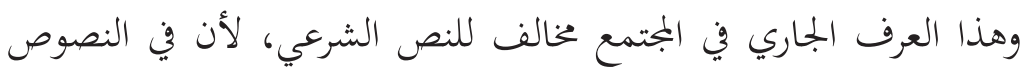
الشرعية يشترط في بيع الذهب بالذهب أن يكون مثلا بمثل غير متفاضل وأن

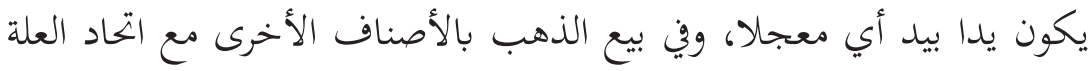

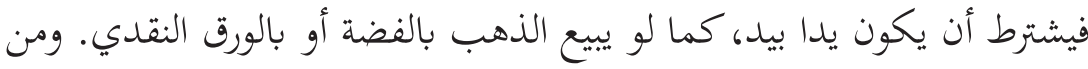

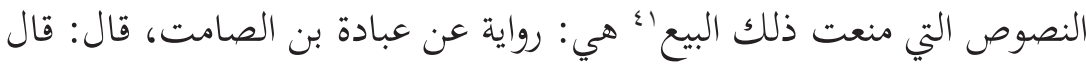

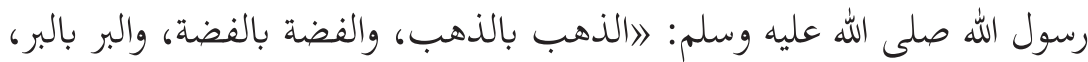

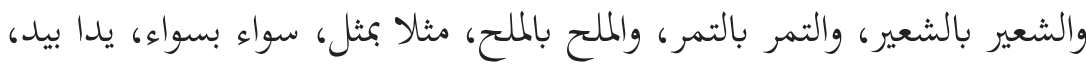

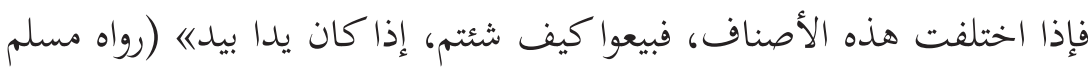

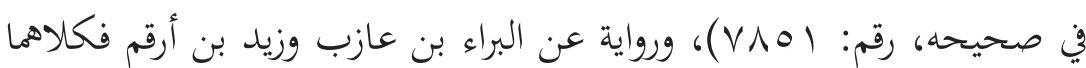

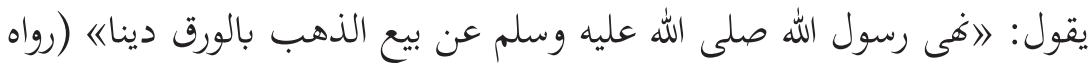

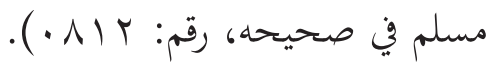

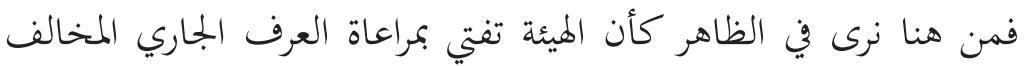
للنص الشرعي وترفض النص. ولا يوجد شيء من النصوص الشرعية التي تبيح

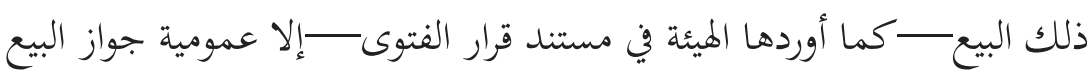

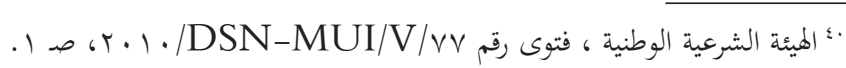

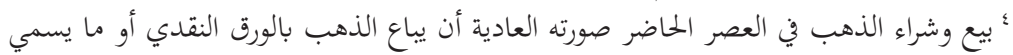

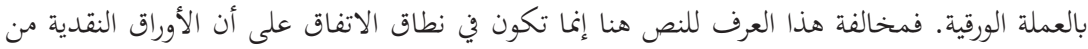

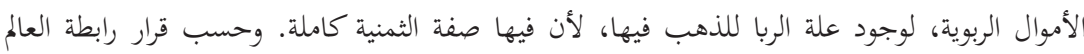

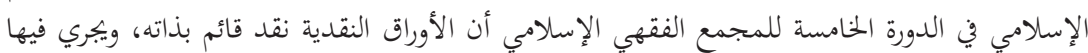

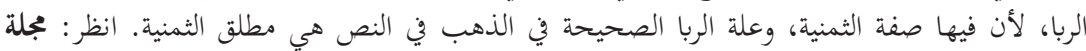

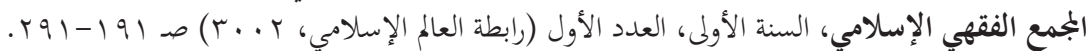
https://archive.org/details/FMAG.। 


$$
\text { وأن البيع لابد أن يكون عن التراضي. }
$$

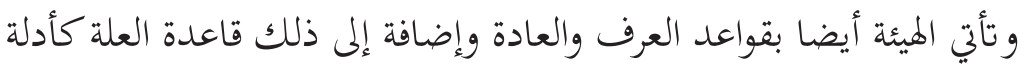

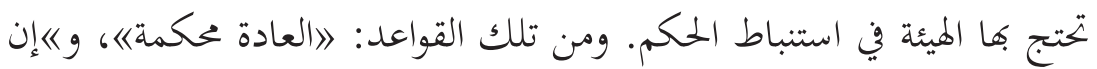

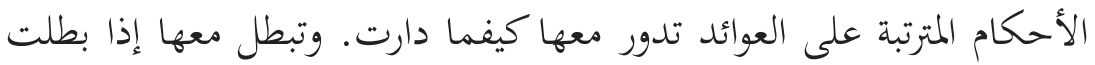

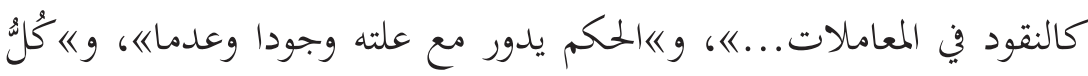

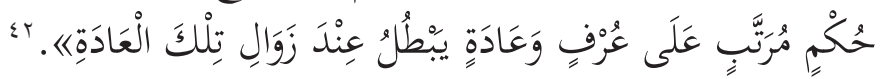

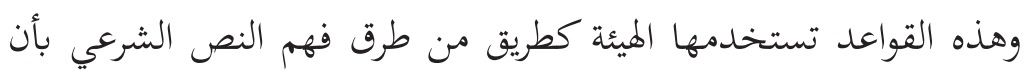

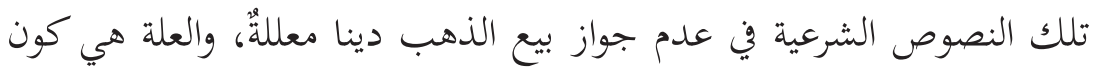

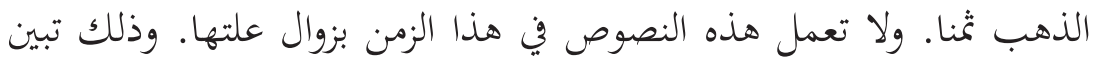

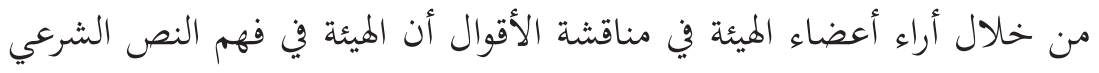

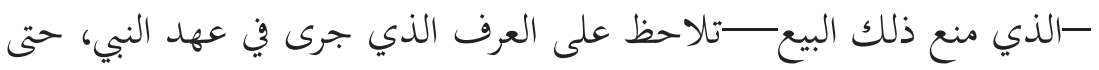

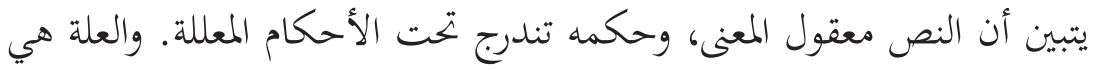

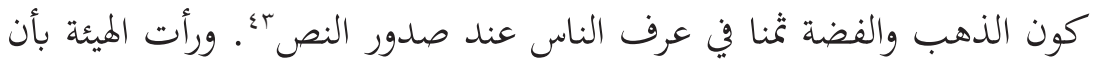

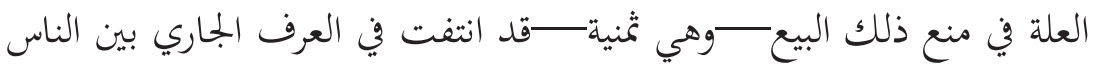

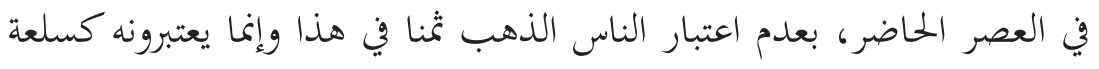

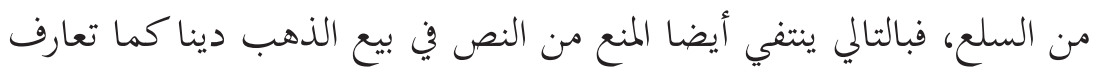

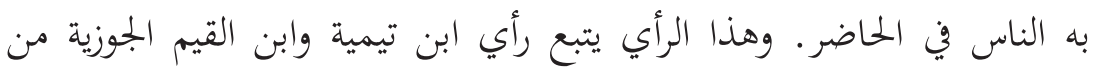
المتقدمين، وكذلك علي جمعة من الفقهاء المعاصرين.

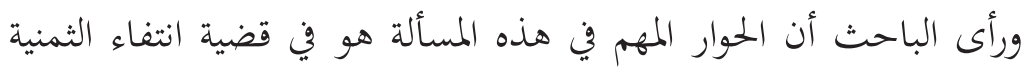

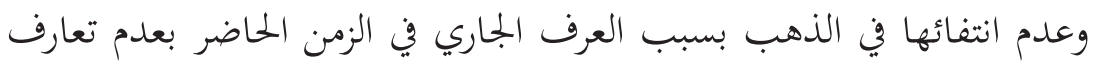

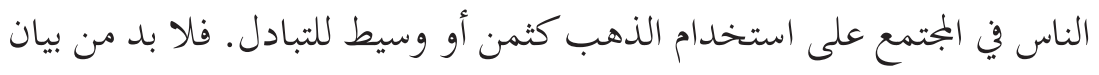

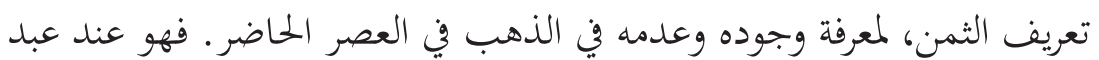

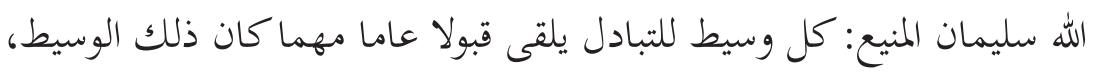




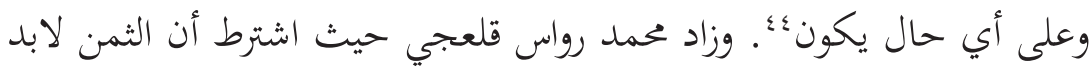

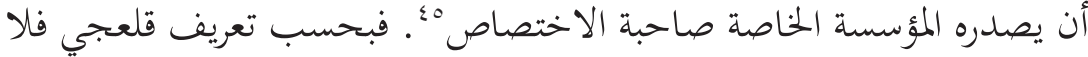

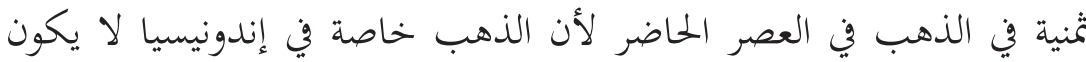

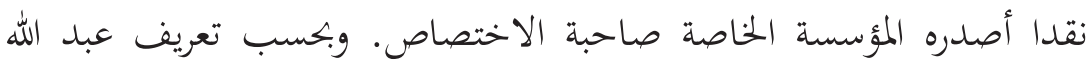

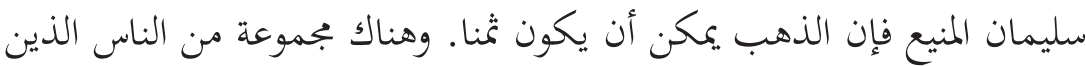

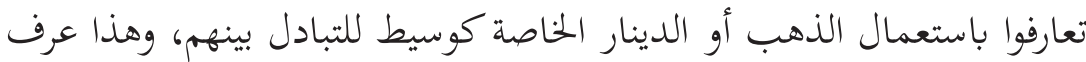

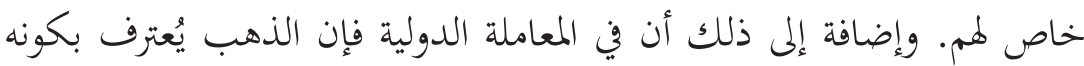

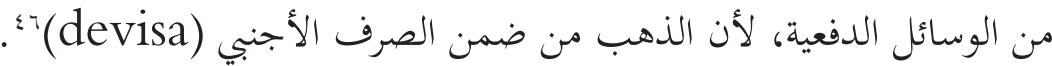

الخاتمة

$$
\text { والخلاصة من البحث السابق: }
$$

1. إن العرف وإن كان مخالفا للنص الشرعي، في بعض الحالات، يمكن أن أن إناء

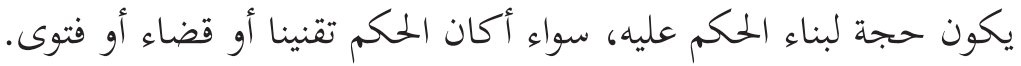

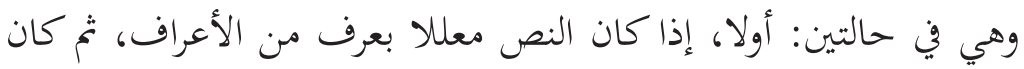

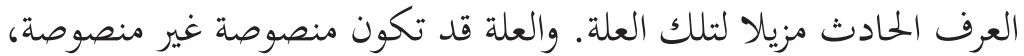
فإذا كانت العلة مستنبطة فينشأ الخلاف في اعتبار تلك العلة.

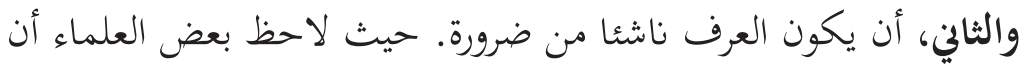

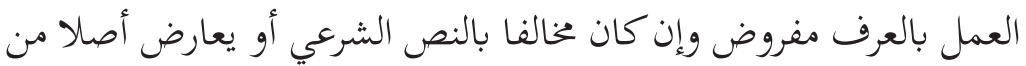

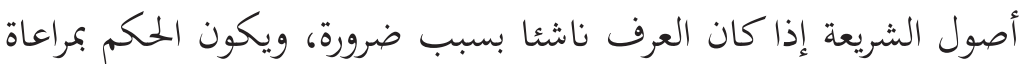

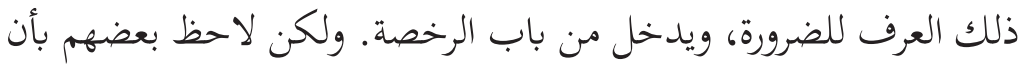

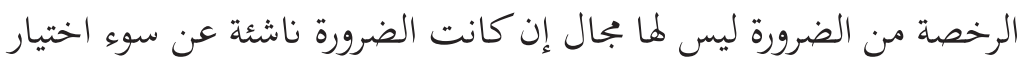
الفرد أو من رغبات غير مشروعة ومعاملات محرمة.

ع ؛ عبد الله سليمان المنيع، بجوث في الاقتصاد الإسلامي (مكة المكرمة: المكتب الإسلامي، . $\wedge V)$ ص ص (799) هـ محمد رواس قلعجي، المعاملات المالية في ضوء الفقه والتشريع (بيروت: دار النفائس، 999 99)،

. $\mathrm{h}(\mathrm{r}$. IV , Nazaruddin Malik, Ekonomi Internasional (Malang: UMM Press $\Sigma$ ฯ 
r. أن العرف الذي التفتت إليه الهيئة الشرعية الوطنية في صدور فتوى إباحة

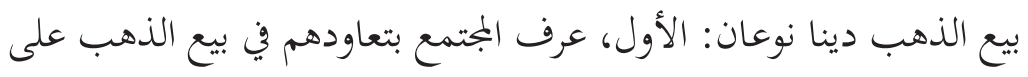

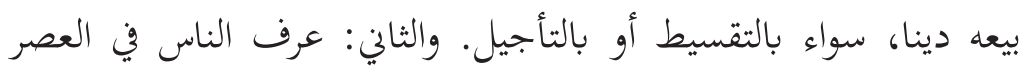

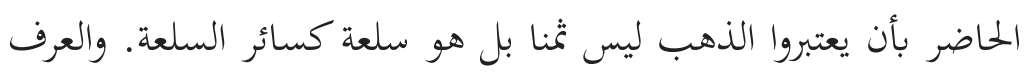

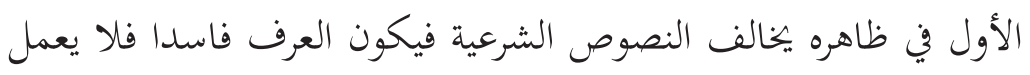

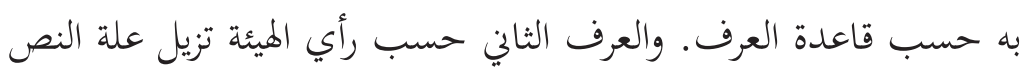

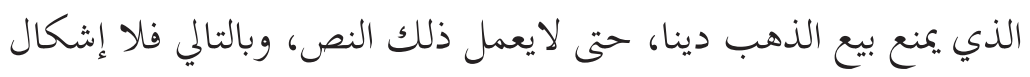

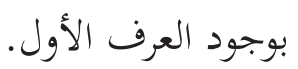

\section{المصادر والمراجع}

ابن منظور. لسان العرب. القاهرة: دار المعارف. د ت. أحمد فهمي أبو سنة. العرف والعادة في رأي الفقهاء. القاهرة: مطبعة الأزهر، ه $19 \leqslant V^{\prime} 61$ b

جلال الدين عبد الرحم السيوطي. الأشباه والنظائر. بيروت: دار الكتب

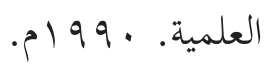

حسنين محمود حسنين. 》امفهوم العرف في الشريعة الإسلامية|ن. مجلة الشريعة

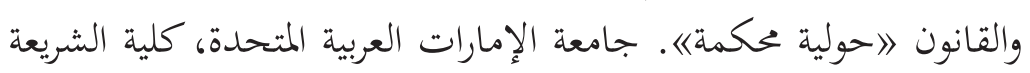

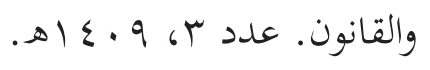

زين الدين بن إبراهيم ابن نجيم (ت . . V هـ). الأشباه والنظائر في مذهب أبي

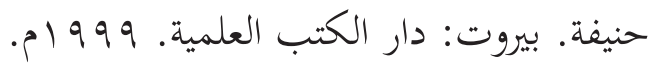

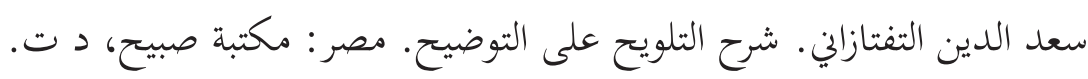
سعيد الكردي النورسي. الكلمات - رسالة النور. ترجمة إحسان قاسم الصالحي.

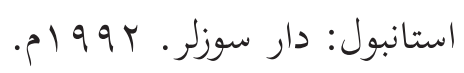

عبد الله بن أحمد النسفي (ت V. V هـ). لالمستصفى《)، في وهبة الزحيلي،

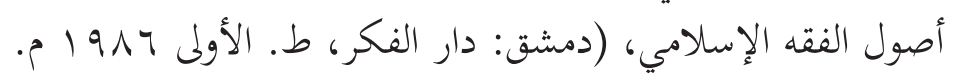


عبد الله سليمان المنيع. بحوث في الاقتصاد الإسلامي. مكة المكرمة: المكتب الإسلامي. 1997.

عبد العزيز عبد الرحمن المشعل. أثر العرف والعادة في دراسة النوازل الفقهية.

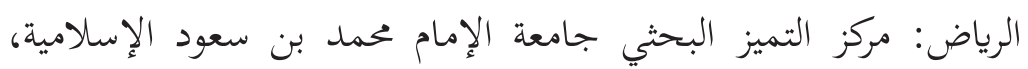
.

عبد الوهاب خلاف. مصادر التشريع الإسلامي فيما لا نص فيه، الكويت:

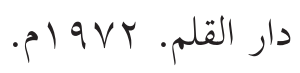

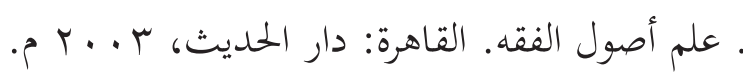

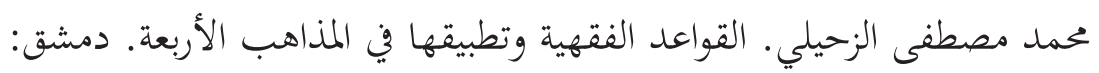

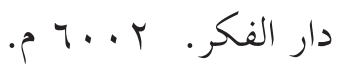

محمد حسن هيتو . الوجيز في أصول التشريع الإسلامي. بيروت: مؤسسة الرسالة. .

محمد أبو زهرة. مالك حياته وعصره آراؤه الفقهية. القاهرة: دار الفكر العربي،

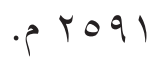

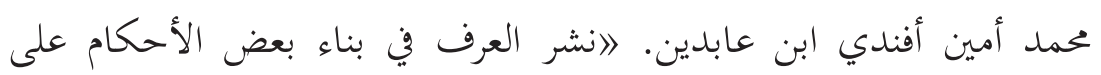

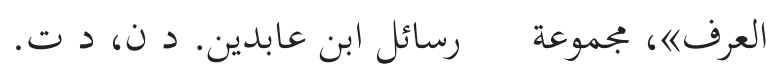

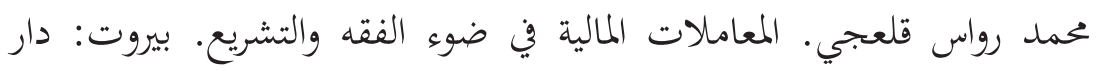

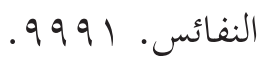

محمد مصطفى المراغي. الاجتهاد في الإسلام. القاهرة: المكتب الفني للنشر، ا

مسلم بن الحجاج النيسابوري. المسند الصحيح المختصر بنقل العدل عن العدل

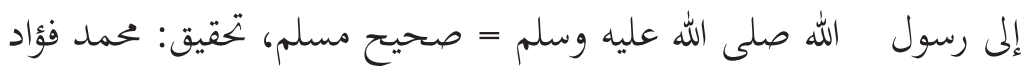

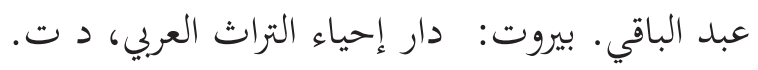

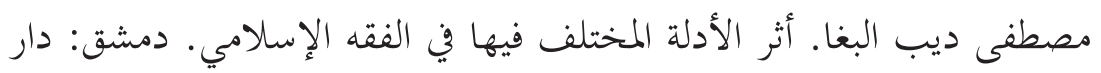

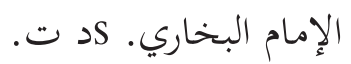


مصطفى أحمد الزرقا. المدخل الفقهي العام. دمشق: دار القلم، ط. ب، سنة $\cdot r \varepsilon \cdot r$

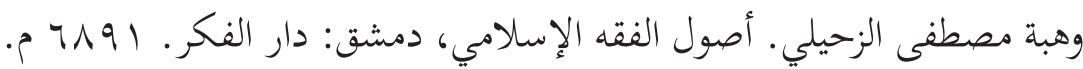

يوسف القرضاوي. عوامل السعة والمرونة في الشريعة الإسلامية. الكويت: المجلس

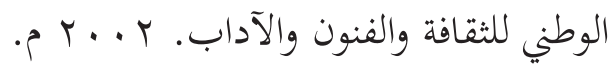

يعقوب بن عبدالوهاب الباحسين. قاعدة العادة محكمة دراسة نظرية تأصيلية

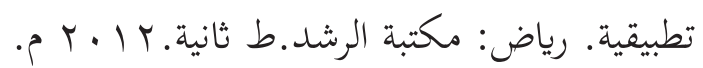

Salinan Fatwa Dewan Syariah Nasional (DSN-MUI) No. 77/DSN-MUI/V/2010 Tentang Jual Beli Emas Secara Tidak Tunai.

Majelis Ulama Indonesia, "Pedoman Penetapan Fatwa MUI”, Peraturan Organisas Majelis Ulama 2015.

Ma’ruf Amin. Solusi Hukum Islam sebagai Pendorong Arus Baru Ekonomi Syariah di Indonesia. Malang: UIN Maulana Malik Ibrahim Malang. 2017.

Nazaruddin Malik. Ekonomi Internasional. Malang: UMM Press. 2017. 